\title{
Immunoreactive folate-binding proteins from human saliva
}

\author{
Isolation and comparison of two distinct species
}

\author{
Rama S. VERMA and Aśok C. ANTONY* \\ Division of Hematology-Oncology, Department of Medicine, Indiana University School of Medicine, \\ Indianapolis, IN 46202, U.S.A.
}

\begin{abstract}
Human saliva contains a single $72000-M_{\mathrm{r}}$ species which specifically reacted with rabbit anti-[human placental folate receptor (PFR)] serum on SDS/PAGE and Western blots. Although a specific radioimmunoassay for human PFR and related folate-binding proteins (FBPs) identified $55 \mathrm{ng}$ of cross-reacting material (CRM) per mg of crude salivary proteins, only a minor fraction (1.6 ng) specifically bound radiolabelled folate. The major fraction of CRM did not contain bound endogenous folate and did not bind radiolabelled folates. On the basis of folate binding, salivary CRM species to PFR were designated as either functional (f-FBP) or non-functional (nf-FBP) species respectively. nf-FBPs and f-FBPs were isolated by different purification schemes. Both purified f-FBPs and nf-FBPs migrated as a single apparent $72000-M_{r}$ species on SDS/PAGE, but on Sephacryl S-200 gel filtration and sucrose-density-gradient ultracentrifugation they were eluted/sedimented with $40000-M_{\mathrm{r}}$ markers. Each microgram of purified f-FBP and nf-FBP was measured in the radioimmunoassay for PFR as being equivalent to $18 \mathrm{ng}$ and $24 \mathrm{ng}$ of CRM respectively, indicating low epitoperelatedness to PFR. The $K_{\mathrm{d}}$ of f-FBPs was $50 \mathrm{pM}$ and $0.94 \mathrm{~mol}$ of folate was bound $/ \mathrm{mol}$ of protein. $\mathrm{f}$-FBPs exhibited an unusual dependence on Triton X-100 for optimal ligand binding, despite the fact that Triton X-100 micelle binding was not demonstrated. The relative order of affinity of f-FBPs for pteroylglutamate $>$ methotrexate $>5$-formyltetrahydrofolate $>5$-methyltetrahydrofolate was also distinct from that of purified PFR. Whereas amino acid and carbohydrate analysis revealed that nf-FBP $\left(M_{\mathrm{r}} 51400\right)$ and f-FBP $\left(M_{\mathrm{r}} 39200\right)$ were distinct glycoproteins with 8 and $13 \%$ carbohydrate respectively, isoelectric focusing and immunological studies suggested some structural identity. The presence of $\mathrm{f}-\mathrm{FBP}$ and $\mathrm{nf}-\mathrm{FBP}$ in normal saliva raises new questions about their possible role in vivo.
\end{abstract}

\section{INTRODUCTION}

High-affinity folate-binding proteins (FBPs) have been identified in various human tissues (reviewed in [1,2]). Externally oriented membrane-associated hydrophobic FBPs play an important transport role as folate receptors (FR) in the binding and uptake of folates in several malignant [3-8] and normal [9-11] human cells in vitro. Although soluble FBPs exhibit similar affinities for pteroylglutamate (PteGlu, folic acid) and various folate analogues, have a 1:1 molar stoichiometric ratio of PteGlu binding and share antigenic determinants with solubilized hydrophobic FR, they are intrinsically hydrophilic and do not bind detergent [12-16]. Biosynthetic [15,16] and structural analyses $[12-14,16,17]$ indicate a precursor-product relationship between hydrophobic FR and soluble FBP which can be mediated in vivo by either $(a)$ an endogenous hydrophobic FR-directed metalloproteinase $[16,18,19]$ which endoproteolytically releases a lower$M_{\mathrm{r}}$ soluble FBP or $(b)$ endogenous glycosyl-phosphatidylinositol (GPI)-specific phospholipases which can release soluble FBP with a polypeptide structure identical with that of GPI-linked FR [20-22]. Thus, insofar as the ligand-binding site of soluble FBP is not destroyed or occupied by endogenous folate, an FBP species devoid of its ligand-binding site would be smaller than native hydrophobic FR or FR-derived soluble FBPs; however, similar forms have not been characterized in vivo. Isolation of multiple FBP/FR cDNA clones from various human cells and tissues [23-27] reveal significant similarity; however, they are not identical, which is indicative of heterogeneity among trans- criptionally active FR genes within a multigene family. Whereas FBP/FR cDNA exhibit approx. 30\% similarity to riboflavinbinding protein (RfBP) cDNA [28], there is no evidence for similarity at the protein level between FBP and RfBPs.

The functional role that soluble FBPs play in folate metabolism is as yet unclear. Although previous reports suggested that the presence of soluble milk FBPs in the intestinal lumen may have a significant role in modulating absorption of folate [29-32], except for one report which identified salivary folate-binding activity in 1 out of 30 normal individuals [33], no other results are available as to whether FBPs are normal constituents of various gastrointestinal secretions.

Although FR/FBPs have conventionally been detected solely on the basis of their radioligand-binding properties, a sensitive specific radioimmunoassay for placental FR (PFR) [34] demonstrated its utility in studies on regulation of FBPs $[9,35]$. Since preliminary experiments revealed a disproportionally higher content of immunoreactive FBPs in crude saliva than the amount of FBP detected by radioligand-binding, we characterized salivary FBPs after their isolation to define the basis for this discrepancy.

\section{EXPERIMENTAL}

\section{Materials}

${ }^{125}$ I-labelled pteroylglutamate (histamine derivative), $\left[{ }^{125} \mathrm{I}-\right.$ PteGlu(HD)], an iodinated histamine derivative of folic acid, 1-carboxy-3-\{N-[2-(4-imidazolyl)ethyl]carbamoyl $\}-1$-pteroyl-

Abbreviations used: f, functional; nf, non-functional; FBPs, folate-binding proteins; FR, folate receptor; PteGlu, pteroylglutamate (folic acid); ${ }^{125}$ IPteGlu(HD), ${ }^{125}$ I-labelled pteroylglutamate (histamine derivative); CRM, cross-reactive material; PFR, placental folate receptor; RfBP, riboflavinbinding protein; GPI, glycosyl-phosphatidylinositol; PBS, phosphate-buffered saline (10 mM- $\mathrm{K}_{2} \mathrm{PO}_{4}, \mathrm{pH} 7.5$, containing $\left.150 \mathrm{mM}-\mathrm{NaCl}\right)$; PT, $10 \mathrm{~mm}-$ $\mathrm{K}_{2} \mathrm{PO}_{4}$, pH 7.5, containing $1 \%$ Triton X-100; SAT, 10 mM-sodium acetate acetic acid, pH 4.5, containing $1 \%$ Triton X-100; IC 50 is defined in the text.

* To whom correspondence should be addressed. 
aminopropane (sp. radioactivity $2200 \mathrm{Ci} / \mathrm{mmol}, 99 \%$ pure [9]), was from du Pont-New England Nuclear. $\left[3,5^{\prime}, 7,9-{ }^{3} \mathrm{H}\right] \mathrm{PteGlu}$ (potassium salt, in $1 \%$ ascorbic acid; sp. radioactivity $50 \mathrm{Ci} /$ mmol, purified $>99 \%$ [13]) and ${ }^{125}$ I-labelled protein A (sp. radioactivity $38 \mathrm{mCi} / \mathrm{mg}$ ) were from Amersham International. Apo- and holo-RfBP from chicken egg white (purity $>99 \%$ ), PteGlu (98\% pure), 5-methyltetrahydrofolate $(95 \%$ pure), 5-formyltetrahydrofolate (95\% pure) and methotrexate (90\% pure) were from Sigma.

\section{Isolation of PFR, preparation of anti-PFR serum and radioimmunoassay for PFR}

PFR was purified to apparent homogeneity, and rabbit polyclonal anti-PFR serum was prepared against the purified protein as described in [36]. The specific radioimmunoassay for PFR was carried out exactly as described previously [34]. The doseresponse curve generated with PFR and all unknown samples were routinely analysed in triplicate. The concentration of total CRM in each unknown sample was determined from the standard curve only after $(a)$ at least three values of each unknown sample were obtained that fell well within the standard curve and $(b)$ determination of the mean CRM per $\mu \mathrm{g}$ of unknown sample did not deviate by more than $10 \%$ for each of the three values tested. The values expressed as ng of CRM (to PFR)/mg of protein are not absolute, but only relative, to PFR.

\section{Manoeuvres to remove endogenous folate from saliva}

Unless specified, fresh crude saliva maintained at $4{ }^{\circ} \mathrm{C}$ was centrifuged at $30000 \mathrm{~g}$ for $30 \mathrm{~min}$ and filtered $(0.22 \mu \mathrm{m}$-pore-size filter) before use. (a) The $\mathrm{pH}$ of $1 \mathrm{ml}$ of saliva was adjusted to pH 3.0 with $1 \mathrm{M}-\mathrm{HCl}$ and an equal volume of $6 \mathrm{M}$-guanidinium chloride was added. The mixture was sequentially dialysed $\left(M_{\mathrm{r}}\right.$ cut-off $=6000$ ) against $50 \mathrm{ml}$ of $6 \mathrm{M}$-guanidinium chloride with six changes of guanidinium chloride solution every $12 \mathrm{~h}$, followed by 4 litres of 10 mM- $\mathrm{K}_{2} \mathrm{PO}_{4}, \mathrm{pH} 7.5$, with eight changes of this buffer every $12 \mathrm{~h}$. (b) Saliva $(1 \mathrm{ml})$ was dialysed against 1 litre of phosphate-buffered saline (PBS) with eight changes of PBS every $12 \mathrm{~h}$. (c) The $\mathrm{pH}$ of two $1 \mathrm{ml}$ portions of saliva was decreased to $\mathrm{pH} 4.5$ or $\mathrm{pH} 3$ by addition of $1 \mathrm{M}$-acetic acid, followed by dialysis against 1 litre of $10 \mathrm{~mm}$-sodium acetate/acetic acid, $\mathrm{pH} 4.5$, or 1 litre of $0.2 \mathrm{M}$-acetic acid, $\mathrm{pH} \mathrm{3,} \mathrm{respectively,} \mathrm{with}$ eight buffer changes every $12 \mathrm{~h}$, followed by four dialyses against 4 litres of PBS every $12 \mathrm{~h}$. After confirmation that the pH was 7.5 , Triton X-100 was added to achieve a final concentration of $1 \%$, and all samples were analysed for binding of $\left[{ }^{125} \mathrm{I}\right]$ PteGlu(HD) and $\left[{ }^{3} \mathrm{H}\right]$ PteGlu.

\section{Donor characteristics and method of saliva collection}

These studies were carried out over a 3-year period during which more than 20 normal human volunteers from several racial groups (Caucasians, Orientals, Asians, African Americans) between the ages of 20 and 40 years periodically participated as donors of saliva. The results which relate to the proportion of nfFBPs and f-FBPs from single donors were consistently reproducible on different occasions from more than ten different individuals. Except for large-scale collection of saliva, all individuals donated saliva after breakfast (approx. $09.00 \mathrm{~h}$ ). Thorough rinsing of the oral cavity was a prerequisite before donation of saliva which was induced by sucking lemon drops (E. J. Brach Corp., Chicago, IL, U.S.A.), which contained no intrinsic folatebinding activity. In addition, both quantitative and qualitative analysis indicated no differences in FBPs in individuals whose salivary secretions were induced by chewing pieces of Indiarubber or lemon drops.

\section{Purification of salivary f-FBPs}

Endogenous folate removal. Saliva (5 litres) collected from many normal volunteers in 1 day was centrifuged twice at $30000 \mathrm{~g}$ for $1 \mathrm{~h}$. After the supernatant had been filtered, endogenous folate was removed as described in [12], and the clear supernatant (processed saliva) was used to isolate f-FBPs.

Precipitation and dialysis. $\left(\mathrm{NH}_{4}\right)_{2} \mathrm{SO}_{4}(300 \mathrm{~g})$ was added to 6 litres of processed saliva and the mixture was stirred for $1 \mathrm{~h}$, and centrifuged at $30000 \mathrm{~g}$ for $30 \mathrm{~min}$. To the supernatant an additional $300 \mathrm{~g}$ of $\left(\mathrm{NH}_{4}\right)_{2} \mathrm{SO}_{4}$ was added, and this cycle was repeated three times. The resulting four pellets were pooled and resuspended in $500 \mathrm{ml}$ of $10 \mathrm{~mm}-\mathrm{K}_{2} \mathrm{PO}_{4}(\mathrm{pH} \mathrm{7.5)/1 \%}$ Triton X100 (PT) and dialysed against 4 litres of PT with four buffer changes every $8 \mathrm{~h}$.

Concentration. The dialysed sample was diluted 10-fold with $10 \mathrm{~mm}$-sodium acetate acetic acid ( $\mathrm{pH} \mathrm{4.5)/1 \%} \mathrm{Triton} \mathrm{X-100}$ (SAT) and applied to $5 \mathrm{ml}$ of CM-cellulose [38] equilibrated with SAT. The column was washed successively with $500 \mathrm{ml}$ of SAT, $500 \mathrm{ml}$ of $0.2 \mathrm{M}$-acetic acid (pH 3)/1\% Triton X-100, 1 litre of SAT, 1 litre of SAT $/ 50 \mathrm{~mm}-\mathrm{NaCl}$, and was finally batch-eluted with $5 \mathrm{ml}$ of SAT $/ 250 \mathrm{~mm}-\mathrm{NaCl}$, and the $\mathrm{pH}$ of the eluate raised to 7.5 by addition of $0.1 \mathrm{M}-\mathrm{NaOH}$.

Gel filtration. Samples $(1 \mathrm{ml})$ of CM-cellulose eluate were sequentially injected into a Protein-Pak SW 300 h.p.l.c. gelfiltration column $(7 \mathrm{~mm} \times 30 \mathrm{~cm})$, which was equilibrated and eluted with PT [16]. Fractions of volume $0.5 \mathrm{ml}$ were collected and analysed by the radioligand-binding assay [16], and fractions containing maximal folate-binding activity were pooled.

\section{Preparation of non-immune serum- and anti-PFR serum-Sepharose}

Non-immune or anti-PFR serum $(20 \mathrm{ml})$ [36] and $7 \mathrm{~g}$ of CNBr-activated Sepharose 4B (Pharmacia) were incubated at $4{ }^{\circ} \mathrm{C}$ for $48 \mathrm{~h}$, filtered, and the retained beads ( $25 \mathrm{~g}$ wet wt.) were incubated with $100 \mathrm{ml}$ of $1 \mathrm{M}$-Tris base for $2 \mathrm{~h}$ at $4{ }^{\circ} \mathrm{C}$. The beads were then washed successively with 1 litre of $1 \mathrm{M}$-Tris base, 1 litre of water, 1 litre of $0.1 \mathrm{M}$-glycine $/ \mathrm{HCl}(\mathrm{pH} 2.5) / 1 \mathrm{M}-\mathrm{NaCl}, 1$ litre of water and finally 1 litre of PBS, and resuspended in $75 \mathrm{ml}$ of PBS.

\section{Purification of salivary nf-FBPs}

Affinity chromatography. Crude saliva (1 litre) was centrifuged at $30000 \mathrm{~g}$ for $1 \mathrm{~h}$, filtered $(0.22 \mu \mathrm{m}$-pore-size filter $)$, and incubated with $50 \mathrm{ml}$ ( $16 \mathrm{~g}$ wet wt.) of non-immune serum-Sepharose for $48 \mathrm{~h}$. After centrifugation at $3000 \mathrm{~g}$ for $30 \mathrm{~min}$, the supernatant was aspirated and mixed with $25 \mathrm{ml}(8 \mathrm{~g}$ wet wt.) of anti(PFR serum)-Sepharose. After incubation for $48 \mathrm{~h}$, the pellet was recovered and subjected to three centrifuge-wash cycles with 12 vol. of PBS. The pellet was then incubated with $25 \mathrm{ml}$ of $6 \mathrm{M}$ guanidinium chloride for $2 \mathrm{~h}$, and, after centrifugation, the supernatant was aspirated, dialysed against 4 litres of PT, with four buffer changes every $8 \mathrm{~h}$ and concentrated by freeze-drying.

Gel filtration. The freeze-dried powder was resuspended in $3 \mathrm{ml}$ of water and subjected to analytical Sephacryl S-200 gel filtration [16]. The fraction containing maximum CRM and protein was further analysed for purity.

\section{Competitive inhibition of $\left[{ }^{3} \mathrm{H}\right] \mathrm{PteGlu}$ binding to f-FBPs by unlabelled folates}

The reaction mixture $(250 \mu \mathrm{l})$ containing PT, CM-cellulose eluate containing f-FBPs $(0.3 \mathrm{pmol})$, and increasing concentrations of various folate analogues $(0.01-10000 \mathrm{nM})$ was mixed at $22^{\circ} \mathrm{C}$ before addition of $\left[{ }^{3} \mathrm{H}\right]$ PteGlu $(2.8 \mathrm{pmol})$. After incubation at $37^{\circ} \mathrm{C}$ for $1 \mathrm{~h},\left[{ }^{3} \mathrm{H}\right] \mathrm{PteGlu}$ binding was determined by h.p.l.c. gel filtration [16]. Each data point was analysed in triplicate. The 
$\mathrm{IC}_{50}$ for each folate analogue was defined as the concentration of unlabelled folate that inhibited $\left[{ }^{3} \mathrm{H}\right] \mathrm{PteGlu}$-binding to $\mathrm{f}-\mathrm{FBPs}$ by $50 \%$. Additional assays [36] were also carried out with purified PFR (5.4 pmol) and $\left[{ }^{3} \mathrm{H}\right]$ PteGlu (16.8 pmol) to define the $\mathrm{IC}_{50}$ with PteGlu and the same folate analogues used in studies with f-FBP. This internal control ensured that any differences in the $\mathrm{IC}_{50}$ of a given folate analogue for f-FBP was not due to differences in contaminants within the folate analogues used (which may have altered affinities for binding to PFR). Such an occurrence would be identified by changes in the $\mathrm{IC}_{50}$ of the folate analogue (using PFR) from that expected from earlier studies using purified preparations of folate analogues and PFR [36]. The value for relative $I_{50}$ of a given folate analogue (relative to $\mathrm{IC}_{50}$ of PteGlu) with f-FBP or PFR was obtained by dividing the value of the $\mathrm{IC}_{50}$ of the folate analogue by the $\mathrm{IC}_{50}$ of PteGlu.

\section{Determination of stoichiometry, amino acid and carbohydrate composition}

Amino acid and carbohydrate analysis of purified f-FBP and nf-FBP and the stoichiometry of folate binding by f-FBP was determined as described in [16]; the $M_{\mathrm{r}}$ of f-FBP was taken as 40000 on the basis of $(a)$ gel-filtration analysis, (b) sucrosedensity gradient ultracentrifugation and (c) amino acid and carbohydrate analysis. The results of amino acid and carbohydrate analysis of $\mathrm{f}$-FBP were expressed as $\mathrm{mol}$ of residue $/ \mathrm{mol}$ of PteGlu bound, whereas nf-FBP results were expressed as mol of residue/mol of FBP assuming an $M_{\mathrm{r}}$ of 40000 , based on analytical gel-filtration and sucrose-density-gradient studies of nf-FBP.

\section{Other methods}

Other methods used in the present study (but not detailed here) were described or referred to in recent publications from our laboratory $[11,16,22]$.

\section{RESULTS}

\section{Identification of distinct FBPs in saliva}

Immunoblot assays revealed that only anti-PFR serum consistently recognized crude salivary FBP in a dose-dependent manner when probed with ${ }^{125} \mathrm{I}$-labelled protein A (Fig. 1a); in contrast, no signal was identified with an equivalent amount of buccal mucosal scrapings. When crude saliva was subjected to SDS/PAGE and Western blots, only anti-PFR serum recognized a single $72000-M_{\mathrm{r}}$ species (Fig. $1 b$ ). Similar findings were obtained with salivary proteins after endogenous folate removal. Furthermore, anti-PFR serum failed to recognize an equivalent amount of purified apo- and holo-RfBPs (Fig. 1), and no folate- binding \{using $20 \mathrm{pmol}$ of $\left[{ }^{3} \mathrm{H}\right] \mathrm{PteGlu}$ or $2 \mathrm{pmol}$ of ${ }^{125} \mathrm{I}-$ PteGlu(HD) $\}$ to purified apo- or holo-RfBPs (1 mg each) was demonstrable in the absence or presence of Triton X-100 (results not shown). These studies indicated that anti-PFR serum recognized only a single FBP-like moiety of $M_{\mathrm{r}} 72000$ in saliva and therefore only reacted with this species when used in a radioimmunoassay with PFR to generate the standard curve. With fresh crude saliva, $3.2 \mathrm{fmol}$ of ${ }^{125} \mathrm{I}-\mathrm{PteGlu}(\mathrm{HD})$ was bound/ mg of protein (Table 1 and Fig. 2), and Sephacryl S-200 gel filtration revealed that the single ${ }^{125} \mathrm{I}-\mathrm{PteGlu}(\mathrm{HD})$-bound peak fraction at $M_{\mathrm{r}} 40000$ corresponded to the same fraction exhibiting maximal CRM to PFR (result not shown). ${ }^{125} \mathrm{I}-$ PteGlu(HD) binding was enhanced 10-fold after removal of
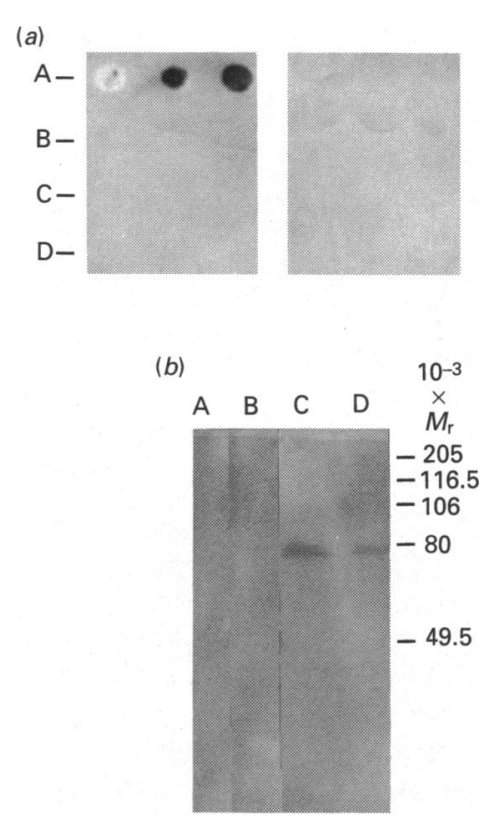

Fig. 1. (a) Immunoblot analysis using anti-PFR serum and non-immuneserum and (b) SDS/PAGE and Western-blot studies

(a): A, crude filtered saliva; B, holo-riboflavin-binding protein; C, apo-riboflavin-binding protein; $D$, solubilized ( $2 \%$ SDS) pellet from buccal mucosal scrapings. Samples $(100 \mu \mathrm{g}, 500 \mu \mathrm{g}$ and $1 \mathrm{mg})$ were applied to nitrocellulose filters, which were probed with antiPFR serum (left) and non-immune serum (right), followed by ${ }^{125} \mathrm{I}$ labelled Protein A and autoradiography [18]. (b) Crude undialysed (lanes A and C) and dialysed (processed) (lanes B and D) salivary proteins (200 $\mu \mathrm{g}$ each), were probed with non-immune serum (lanes $A$ and $B$ ) or anti-PFR serum (lanes $C$ and D) followed by ${ }^{125} I-$ labelled protein A [18]. The $M_{\mathrm{r}}$ values of known marker proteins are indicated on the right (myosin, 205000; $\beta$-galactosidase, 116500 ; phosphorylase $b, 106000$; albumin, 80000; ovalbumin, 49500).

Table 1. Analysis of crude saliva before and after endogenous folate removal for ligand-binding, affinity and immunoreactive material in the radioimmunoassay for PFR radioimmunoassay

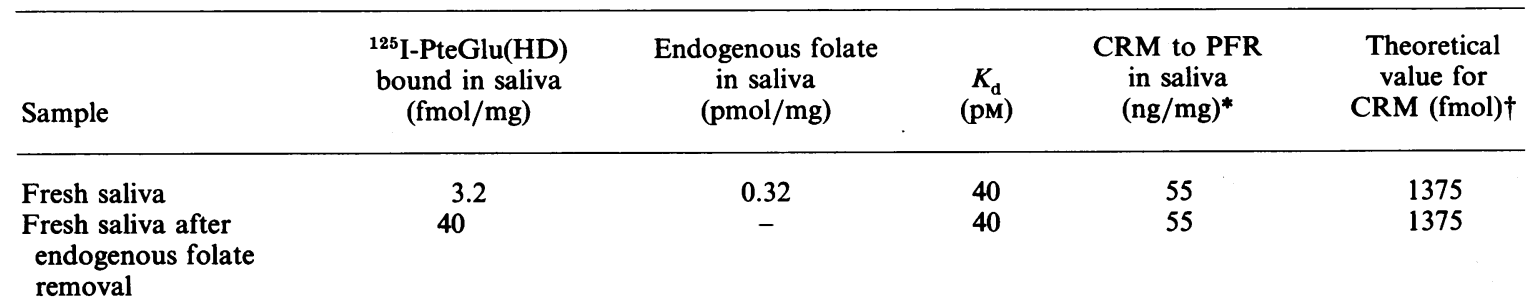

* These are not absolute values and only a function of epitope-relatedness between salivary FBPs (CRM) and PFR.

$\dagger$ Based on an $M_{\mathrm{r}}$ of 40000 . 


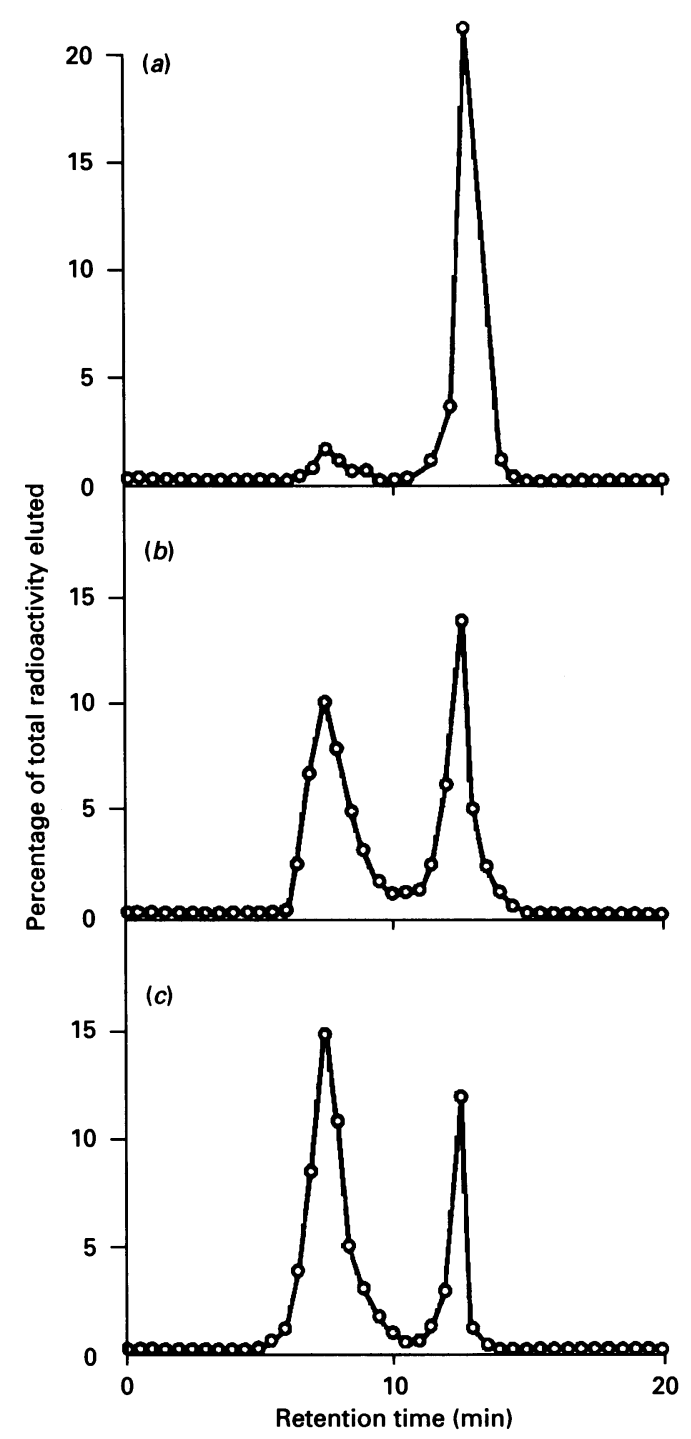

Fig. 2. H.p.l.c. gel-filtration analysis of the binding of ${ }^{125} \mathrm{I}-\mathrm{PteGlu}(\mathrm{HD})$ to salivary FBPs

(a) Crude human saliva (100 $\mu \mathrm{l} ; 100 \mu \mathrm{g}$ of protein), (b) processed saliva $(100 \mu \mathrm{l} ; 90 \mu \mathrm{g}$ of protein) or $(c)$ purified f-FBPs $(5 \mu \mathrm{g}$ of protein) were incubated for $1 \mathrm{~h}$ at $37^{\circ} \mathrm{C}$, in a final volume of $250 \mu \mathrm{l}$ containing PT and ${ }^{125} \mathrm{I}$-PteGlu(HD) $(25 \mathrm{fmol})$ before application to an h.p.l.c. SW300 Protein-Pak column [16]. Fractions ( $0.5 \mathrm{ml}$ each) were collected and counted for radioactivity. The second radioactive peak corresponds to free (unbound) ${ }^{125} \mathrm{I}-\mathrm{PteGlu}(\mathrm{HD})$. Recovery of applied radioactivity was greater than $99 \%$, and specific radioligand binding comprised $85-95 \%$ of total radioligand binding.

endogenous folate, which did not change the affinity of these FBPs for ${ }^{125}$ I-PteGlu(HD) (Table 1). The radioimmunoassay for PFR revealed a total of $55 \mathrm{ng}$ of $\mathrm{CRM} / \mathrm{mg}$ of saliva. Assuming that the value of $55 \mathrm{ng}$ was quantitative in absolute terms, and the $M_{\mathrm{r}}$ of this species was 40000 on the basis of gel filtration, this translated to $1375 \mathrm{fmol}$ of immunoreactive $\mathrm{FBP} / \mathrm{mg}$ of saliva, a value that was 30 -fold greater than that observed by the specific radioligand-binding assay used to quantify salivary FBP (Table 1). However, these findings could be explained if a species of FBPs in saliva contained a significant amount of endogenous (bound) folate that was poorly released by conventional methods to remove folate. However, exhaustive low-pH dialysis failed to increase ${ }^{125} \mathrm{I}$-PteGlu(HD) binding greater than that achieved by charcoal adsorption of low-pH-dissociated endogenous folate (Table 2). Since FBP from cow's milk has been observed to bind
Table 2. Analysis of crude saliva for ligand-binding after removal of endogenous folate by various methods

Values in parentheses represent the value for ${ }^{125} \mathrm{I}-\mathrm{PteGlu}(\mathrm{HD})-$ binding (in fmol) to fresh saliva before endogenous folate removal.

\begin{tabular}{lcc}
\hline Saliva & $\begin{array}{c}\text { 125I-PteGlu(HD) } \\
\text { bound in saliva } \\
\text { (fmol/mg) }\end{array}$ & $\begin{array}{c}\text { Fold increase } \\
\text { in folate binding } \\
\text { after endogenous } \\
\text { folate removal }\end{array}$ \\
\hline $\begin{array}{l}\text { Dialysed against PBS } \\
\text { After low-pH and } \\
\text { charcoal treatment }\end{array}$ & 3.2 & - \\
$\begin{array}{l}\text { After low-pH dialysis } \\
\text { After guanidinium } \\
\text { chloride and dialysis }\end{array}$ & $\begin{array}{l}28(3.2) \\
26.6(3.2)\end{array}$ & 12.5 \\
\hline
\end{tabular}

some folate even at $\mathrm{pH} 3$, we employed a strategy wherein salivary FBPs in $3 \mathrm{~m}$-guanidinium chloride were extensively dialysed first against $6 \mathrm{M}$-guanidinium chloride, followed by subsequent dialysis against PBS to remove the denaturant. Despite these efforts, the renatured salivary FBP did not exhibit more binding of ${ }^{125} \mathrm{I}-\mathrm{PteGlu}(\mathrm{HD})$ or $\left[{ }^{3} \mathrm{H}\right] \mathrm{PteGlu}$ than any of the other low-pH-dialysed samples (Table 2). Thus it was unlikely that salivary FBPs contained a major fraction that had endogenous bound folate which would lead to the observed poor binding to radiolabelled folate. Furthermore, saliva did not contain a factor that inhibited or destroyed radiolabelled folate from binding PFR, since there was no inhibition of $\left[{ }^{3} \mathrm{H}\right] \mathrm{PteGlu}$ binding (with $50 \mathrm{pmol}$ of $\left.\left[{ }^{3} \mathrm{H}\right] \mathrm{PteGlu}\right)$ to purified PFR $(25 \mathrm{pmol}$ of PFR) by dialysed saliva (at 4,22 or $37^{\circ} \mathrm{C}$ for $30 \mathrm{~min}$ ), and minimal inhibition (approx. 10\%) by fresh undialysed saliva which was accounted for by endogenous folate (results not shown). The discrepancy between quantification of salivary FBPs by radioligand binding and radioimmunoassay therefore led us to conclude that saliva probably contained two distinct species of FBPs: one species which was quantitatively much less, but which was functionally active in folate binding (designated f-FBP), and another quantitatively major species which was functionally inactive in folate binding (designated nf-FBP).

\section{Isolation of nf-FBPs}

Pilot studies indicated that rabbit anti-PFR serum-Sepharose $(200 \mu \mathrm{l})$ specifically bound more than $95 \%$ of ${ }^{125}$ I-labelled PFR, whereas non-immune serum-Sepharose bound approx. $5 \%$ of affinity-purified ${ }^{125}$ I-labelled PFR (400000 c.p.m. of ${ }^{125} \mathrm{I}$-labelled PFR in $1 \mathrm{ml}$ of PT) [34]. Using the radioimmunoassay for PFR to monitor the purification of nf-FBP, we isolated salivary nfFBPs using anti-PFR serum-Sepharose as a major purification step (Table 3). Quantification of CRM and expression as relative specific radioactivity was only useful as a measurement of relative purification from one step to another. Samples from each step were also analysed by SDS/PAGE to monitor enrichment of 72000- $M_{\mathrm{r}}$ CRM species (Fig. 3b). The Sephacryl S-200 gelfiltration step was important to separate major contaminant proteins unrelated to $40000-M_{\mathrm{r}} \mathrm{nf}-\mathrm{FBP}$, which co-migrated on SDS/PAGE in the approx. $70000-M_{\mathrm{r}}$ region as $\mathrm{nf}-\mathrm{FBP}$, as well as other lower- $M_{\mathrm{r}}$ contaminants; this fact is supported by the marked increase in specific activity of nf-FBP after this step (Table 3), and is observed when SDS/PAGE profiles of the proteins migrating at $M_{\mathrm{r}} 72000$ before and after this step are compared (Fig. $3 a$, lane $\mathrm{B}$ versus lane $\mathrm{C}$ respectively). When the peak fraction of purified nf-FBP (after the gel-filtration step) was re-applied to another Sephacryl S-200 gel-filtration column, the single protein peak which eluted at an apparent $M_{\mathrm{r}}$ of 40000 
Table 3. Purification scheme for nf-FBPs

\begin{tabular}{|c|c|c|c|c|c|}
\hline $\begin{array}{l}\text { Purification } \\
\text { step }\end{array}$ & $\begin{array}{l}\text { Volume } \\
\text { (ml) }\end{array}$ & $\begin{array}{l}\text { Protein } \\
\text { (mg) }\end{array}$ & $\begin{array}{c}\text { Endogenous } \\
\text { folate } \\
\text { (pmol/mg } \\
\text { of protein) }\end{array}$ & $\begin{array}{l}\text { Total CRM by } \\
\text { radioimmunoassay } \\
(\mu \mathrm{g})\end{array}$ & $\begin{array}{l}\text { Relative specific } \\
\text { activity* }\end{array}$ \\
\hline $\begin{array}{l}\text { Human saliva after } \\
\text { centrifugation and } \\
\text { filtration }\end{array}$ & 800 & 1120 & 0.32 & 59.9 & 0.05 \\
\hline $\begin{array}{l}\text { After affinity chromatography } \\
\text { elution, dialysis and } \\
\text { freeze-drying }\end{array}$ & 42 & 12.89 & 0.92 & 40.3 & 3.13 \\
\hline $\begin{array}{l}\text { After Sephacryl S-200 } \\
\text { gel filtration }\end{array}$ & 2.75 & 0.71 & - & $17.6^{*}$ & 24.79 \\
\hline
\end{tabular}

* These values represent a 495 -fold purification with $29 \%$ recovery based on relative-specific-activity comparisons from among sequential purification steps.

(a)
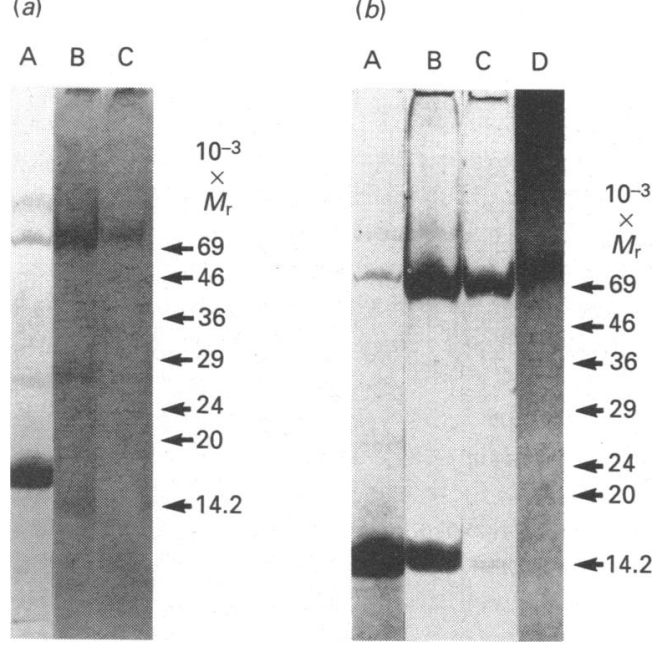

Fig. 3. SDS/PAGE analysis of nf-FBPs $(a)$ and f-FBPs $(b)$ during the purification steps

(a) Lane A, crude saliva after centrifugation; lane B, after affinity chromatography, dialysis and freeze-drying; lane $C$, after Sephacryl S-200 gel filtration. (b) Lane A, processed saliva after endogenous folate removal; lane $\mathrm{B}$, after $\left(\mathrm{NH}_{4}\right)_{2} \mathrm{SO}_{4}$ precipitation and dialysis; lane C, after CM-cellulose elution; lane D, after h.p.l.c. step; $50 \mu \mathrm{g}$ of protein was applied to each well. The direction of electrophoresis was from top to bottom and the $M_{\mathrm{r}}$ values are indicated on the right of each panel.

coincided with the peak of CRM to PFR (Fig. $4 a$ ); in addition, the specific activities of the individual fractions were virtually identical, supporting a high degree of purity of this species. Of additional significance was the fact that this preparation did not bind ${ }^{125} \mathrm{I}-\mathrm{PteGlu}(\mathrm{HD})$ (results not shown). Since f-FBP can be denatured with guanidinium chloride and successfully renatured without significant loss of ${ }^{125} \mathrm{I}-\mathrm{PteGlu}(\mathrm{HD})$-binding capacity (Table 2), and guanidinium chloride was used to elute salivary FBPs bound to anti-PFR serum-Sepharose, the lack of binding of ${ }^{125} \mathrm{I}-\mathrm{PteG}$ (u(HD) to the purified nf-FBP indicated no contamination of nf-FBP by f-FBP. No differences in recovery were observed when purification was carried out with processed or unprocessed saliva.

\section{Isolation of f-FBPs}

Table 4 summarizes the various purification steps involved in the isolation of f-FBPs. Each millilitre of processed saliva
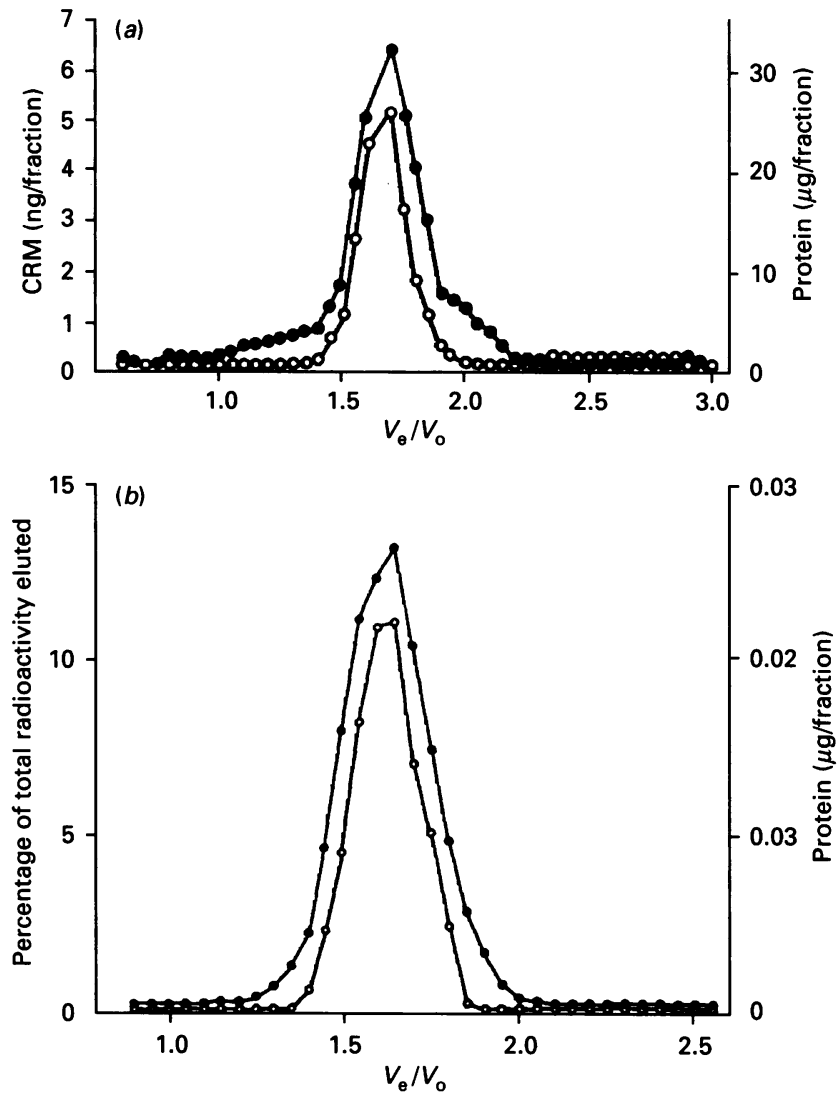

Fig. 4. Analytical Sephacryl S-200 gel-filtration profile of purified nf-FBP (a) and purified f-FBP (b)

The sample consisted of $250 \mu \mathrm{g}$ of purified $\mathrm{nf}-\mathrm{FBPs}$ and $100 \mu \mathrm{g}$ of purified f-FBPs preincubated with $25 \mathrm{fmol}$ of ${ }^{125} \mathrm{I}-\mathrm{PteGlu}(\mathrm{HD})$ in $3 \mathrm{ml}$ of PT followed by dialysis. Fractions of volume $2.75 \mathrm{ml}$ were collected and assayed for protein $(O)$ and CRM to PFR (O) (a) or radioactivity $(O)(b)$.

contained very small quantities of f-FBPs which specifically bound approx. 30-40 fmol of ${ }^{125} \mathrm{I}-\mathrm{PteGlu}(\mathrm{HD})$. This is below the limits of detectability using the relatively-lower-specific radioactivity $\left[{ }^{3} \mathrm{H}\right] \mathrm{PteGlu}$. Therefore, in all steps before $\left(\mathrm{NH}_{4}\right)_{2} \mathrm{SO}_{4}$ precipitation of f-FBPs, we relied on ${ }^{125} \mathrm{I}$-PteGlu(HD)-binding assays to identify f-FBPs. The total amount of $\left[{ }^{3} \mathrm{H}\right] \mathrm{PteGlu}$ bound to f-FBPs after this step was therefore taken as $100 \%$ recovery (Table 4). The purification of f-FBP was also monitored by 
Table 4. Purification scheme for f-FBPs

Values in parentheses represent percentage recovery as discussed in the text.

\begin{tabular}{|c|c|c|c|c|c|}
\hline Purification step & $\begin{array}{l}\text { Volume } \\
\text { (ml) }\end{array}$ & $\begin{array}{l}\text { Protein } \\
\text { (mg) }\end{array}$ & $\begin{array}{l}\text { Endogenous folate } \\
\text { (pmol/mg of protein) }\end{array}$ & $\begin{array}{l}\text { Total }\left[{ }^{3} \mathrm{H}\right] \text { PteGlu } \\
\text { bound (nmol) }\end{array}$ & $\begin{array}{c}\text { Specific activity } \\
\text { (nmol of PteGlu } \\
\text { bound/mg of protein) }\end{array}$ \\
\hline $\begin{array}{l}\text { Human saliva after } \\
\text { centrifugation and } \\
\text { filtration }\end{array}$ & 5000 & 4900 & 0.32 & - & - \\
\hline $\begin{array}{l}\text { After endogenous folate } \\
\text { removal (low pH, charcoal) }\end{array}$ & 6000 & 3840 & - & - & - \\
\hline $\begin{array}{l}\text { After }\left(\mathrm{NH}_{4}\right)_{2} \mathrm{SO}_{4} \\
\text { precipitation }(10-40 \%) \\
\text { followed by dialysis }\end{array}$ & 600 & 1116.5 & - & $8.8(100)$ & 0.0079 \\
\hline $\begin{array}{l}\text { After CM-cellulose elution } \\
\text { with } 0.25 \mathrm{M}-\mathrm{NaCl}\end{array}$ & 15.0 & 22.6 & - & $3.4(38)$ & 0.15 \\
\hline After SW300 h.p.l.c. gel & 2.5 & 0.20 & - & $4.43^{*}(50)$ & 22.15 \\
\hline
\end{tabular}

* This value represents a 2800 -fold purification based on absolute values of 1:1 molar stoichiometry of folate binding by f-FBP.

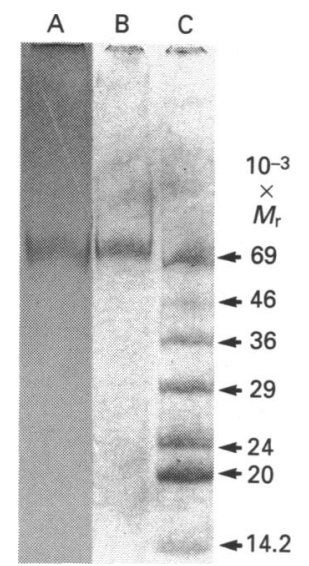

Fig. 5. SDS/PAGE [15\% (w/v) polyacrylamide gels] of purified nf-FBPs (lane A) and f-FBPs (lane B) in the presence of 2-mercaptoethanol

Each protein $(25 \mu \mathrm{g})$, as well as known $M_{\mathrm{r}}$ marker proteins (lane C; albumin, 69000; ovalbumin, 46000; glyceraldehyde-3-phosphate dehydrogenase, 36000; carbonic anhydrase, 29000; trypsinogen, 24000 ; trypsin inhibitor, $20000 ; \alpha$-lactalbumin, 14200), were stained with Coomassie Blue. The $M_{\mathrm{r}}$ values are indicated on the right.

SDS/PAGE analysis of samples after each step, and these data are shown in Fig. 3(b), which reveals progressive purification of the $72000-M_{\mathrm{r}}$ species. Purity of the protein after the final h.p.l.c. gel-filtration purification step was assessed by analytical Sephacryl S-200 gel filtration where ${ }^{125} \mathrm{I}-\mathrm{PteGlu(HD)}$-bound f-FBPs were eluted as a single peak coinciding with protein (Fig. $4 b$, and the specific activities of the individual fractions were virtually identical, suggesting that there was little to no contamination of f-FBPs by nf-FBPs. The purity of the f-FBPs was independently confirmed by stoichiometry of folate binding (carried out during amino acid and carbohydrate analysis) as well as by SDS/PAGE (see below).

\section{Characterization of salivary f-FBPs and nf-FBP}

When the purified proteins were individually analysed by SDS/PAGE (with or without 2-mercaptoethanol), a single 72000- $M_{\mathrm{r}}$ band was observed for f-FBPs and nf-FBPs (Fig. 5), indicating $(a)$ higher $M_{\mathrm{r}}$ values than human PFR $[16,18,22,36]$, milk FBPs [12], KB-cell-membrane-associated FBPs [13-15], and membrane-associated FBPs in pig intestine [37], and that (b) both nf-FBPs and f-FBPs consisted of a single polypeptide chain, consistent with other FBPs $[1,2]$. When subjected to the radioimmunoassay for PFR and related FBPs, $1 \mu \mathrm{g}$ each of apparently homogeneous f-FBPs and nf-FBPs were quantified as $18 \mathrm{ng}$ of CRM and $24 \mathrm{ng}$ of CRM respectively. Although these underestimated values are relative to the reactivity of anti-PFR serum with PFR used in the standard curve, these data nevertheless indicated that the distinct salivary FBPs were antigenically related to, though not identical with, one another. These data, however, emphasized that there was very little epitope-relatedness between PFR and both salivary FBPs. Since the f-FBP was also recognized by anti-PFR serum, f-FBP could have co-purified with nf-FBP, since this species was purified using anti-PFR antibodySepharose as the major purification step. However, since equal amounts of purified f-FBP and nf-FBP were fairly comparably measurable by radioimmunoassay, it follows that the degree of contamination of purified nf-FBP by f-FBP could be no more than its ratio in the crude state, i.e. not more than $3 \%$ of total CRM in saliva, which predominantly consisted of nf-FBP. Furthermore, the fact that purified nf-FBP failed to bind ${ }^{125} \mathrm{I}-$ PteGlu(HD) indicates that nf-FBP was not contaminated with f-FBP. Conversely, purified f-FBPs bound $0.94 \mathrm{~mol}$ of $\left[{ }^{3} \mathrm{H}\right] \mathrm{PteGlu} / \mathrm{mol}$ of protein, which further confirmed the purity of f-FBP as well as its lack of contamination by nf-FBP. The dissociation constant of f-FBPs for ${ }^{125} \mathrm{I}-\mathrm{PteGlu}(\mathrm{HD})$ was $40 \mathrm{pM}$ (Fig. 6a), findings comparable with those for high-affinity FBPs. The results of inhibition of $\left[{ }^{3} \mathrm{H}\right] \mathrm{PteGlu}$ binding to $\mathrm{f}-\mathrm{FBP}$ by PteGlu and various folate analogues was markedly different from those for PFR. The relative $\mathrm{IC}_{50}$ was $1,15,219$ and 875 for PteGlu, 5-methyltetrahydrofolate, methotrexate and 5formyltetrahydrofolate respectively, findings comparable with earlier data for purified PFR and h.p.l.c.-purified folate analogues [36]. In contrast, for $\mathrm{f}-\mathrm{FBP}$, the relative $\mathrm{IC}_{50}$ value was 1 with PteGlu, 2.5 with methotrexate, 20 with 5-formyltetrahydrofolate and 1000 with 5-methyltetrahydrofolate (Fig. 6b). Since the order of highest to lowest relative affinity uniformly proceeds from PteGlu $>$ 5-methyltetrahydrofolate $>$ 5-formyltetrahydrofolate $>$ methotrexate with the internal control PFR, which was characteristic of other FBPs [1,2], the observed differences in relative specificity of binding $\mathrm{f}-\mathrm{FBPs}$ by various folate analogues was not a function of minor contaminants (with high affinity for PFR) which could spuriously alter the $\mathrm{IC}_{50}$ of these folate analogues. These data indicated that the ligand-binding sites of 
Table 5. Amino acid and carbohydrate composition of human salivary f-FBPs and nf-FBPs

N.D., not determined. Values in parentheses indicate the composition as $\mathrm{mol} / 100 \mathrm{~mol}$ of total amino acids.

\begin{tabular}{|c|c|c|}
\hline Item & $\begin{array}{l}\text { f-FBPs (mol } \\
\text { of residue/ } \\
\text { mol of } \\
\text { PteGlu bound) }\end{array}$ & $\begin{array}{c}\text { nf-FBPs } \\
\text { (mol of } \\
\text { residues/ } \\
\text { mol of FBPs)* }\end{array}$ \\
\hline
\end{tabular}

\begin{tabular}{|c|c|c|}
\hline \multicolumn{3}{|l|}{ Amino acid } \\
\hline Alanine & $12(4.6)$ & $24(6.8)$ \\
\hline Arginine & $13(5.0)$ & N.D. \\
\hline Asparagine or aspartic acid & 31 (11.8) & $75(21.3)$ \\
\hline Cysteine & N.D. & N.D. \\
\hline Glutamine or glutamic acid & $43(16.4)$ & $25(7.1)$ \\
\hline Glycine & $22(8.4)$ & $15(4.3)$ \\
\hline Histidine & $9(3.4)$ & $15(4.3)$ \\
\hline Isoleucine & $12(4.6)$ & $17(4.8)$ \\
\hline Leucine & $19(7.3)$ & $31(8.8)$ \\
\hline Lysine & $11(4.2)$ & $30(8.5)$ \\
\hline Methionine & $1(0.4)$ & $1(0.3)$ \\
\hline Phenylalanine & $10(3.8)$ & $13(3.7)$ \\
\hline Proline & $20(7.6)$ & $23(6.5)$ \\
\hline Serine & $20(7.6)$ & $51(14.5)$ \\
\hline Threonine & $10(3.8)$ & $20(5.7)$ \\
\hline Tryptophan & N.D. & N.D. \\
\hline Tyrosine & $11(4.2)$ & $12(3.4)$ \\
\hline Valine & $18(6.9)$ & $31(8.8)$ \\
\hline \multicolumn{2}{|l|}{ Total amino acid residues/ } & 383 \\
\hline$M_{\mathrm{r}} \ldots$ & 33972 & 47487 \\
\hline \multicolumn{3}{|l|}{ Carbohydrate } \\
\hline Sialic acid & 2 & 4 \\
\hline Fucose & 2 & 1 \\
\hline Galactose & 4 & 3 \\
\hline Mannose & 3 & 2 \\
\hline Glucosamine & 16 & 9 \\
\hline Galactosamine & 1 & N.D. \\
\hline $\begin{array}{l}\text { Total carbohydrate residues/ } \\
\text { mol of FBPs... }\end{array}$ & 28 & 19 \\
\hline$M_{\mathrm{r}} \ldots$ & 5249 & 3911 \\
\hline Total number of residues/ & & \\
\hline mol of FBPs... & 290 & 402 \\
\hline Total $M_{\mathrm{r}} \ldots$ & 39221 & 51398 \\
\hline Carbohydrate $(\%) \ldots$ & 13.4 & 7.6 \\
\hline
\end{tabular}

* The $M_{\mathrm{r}}$ was assumed to be 40000 based on analytical Sephacryl S-200 gel-filtration and sucrose-density-gradient-ultracentrifugation data.

f-FBP were distinctly different from prototypical human FBPs. In contrast, nf-FBPs did not bind PteGlu or other reduced or oxidized folate analogues in mono- and poly-glutamated forms (results not shown).

The amino acid and carbohydrate composition of purified nfFBPs and f-FBPs (Table 5) indicated that f-FBP had an $M_{\mathrm{r}}$ of 39221 and nf-FBP had an $M_{\mathrm{r}}$ of 51 398. Carbohydrates comprised 13 and $8 \%$ of the total $M_{\mathrm{r}}$ of f-FBPs and nf-FBPs respectively. Significantly, the majority of amino acid residues/mol of FBP were different between f-FBP and nf-FBP. nf-FBPs contained 121 more amino acid residues than f-FBP, thus accounting for the higher $M_{\mathrm{r}}$. When both purified salivary FBPs were radioiodinated and subsequently analysed by Sephacryl S-200 gel filtration and SDS/PAGE, there was a single species of iodinated protein that corresponded to the elution and migration profile of unlabelled FBPs respectively (results not shown). Since ${ }^{125} \mathrm{I}-$ labelled FBPs were not subjected to additional purification steps before analysis (except for Sephadex G-10 gel filtration to
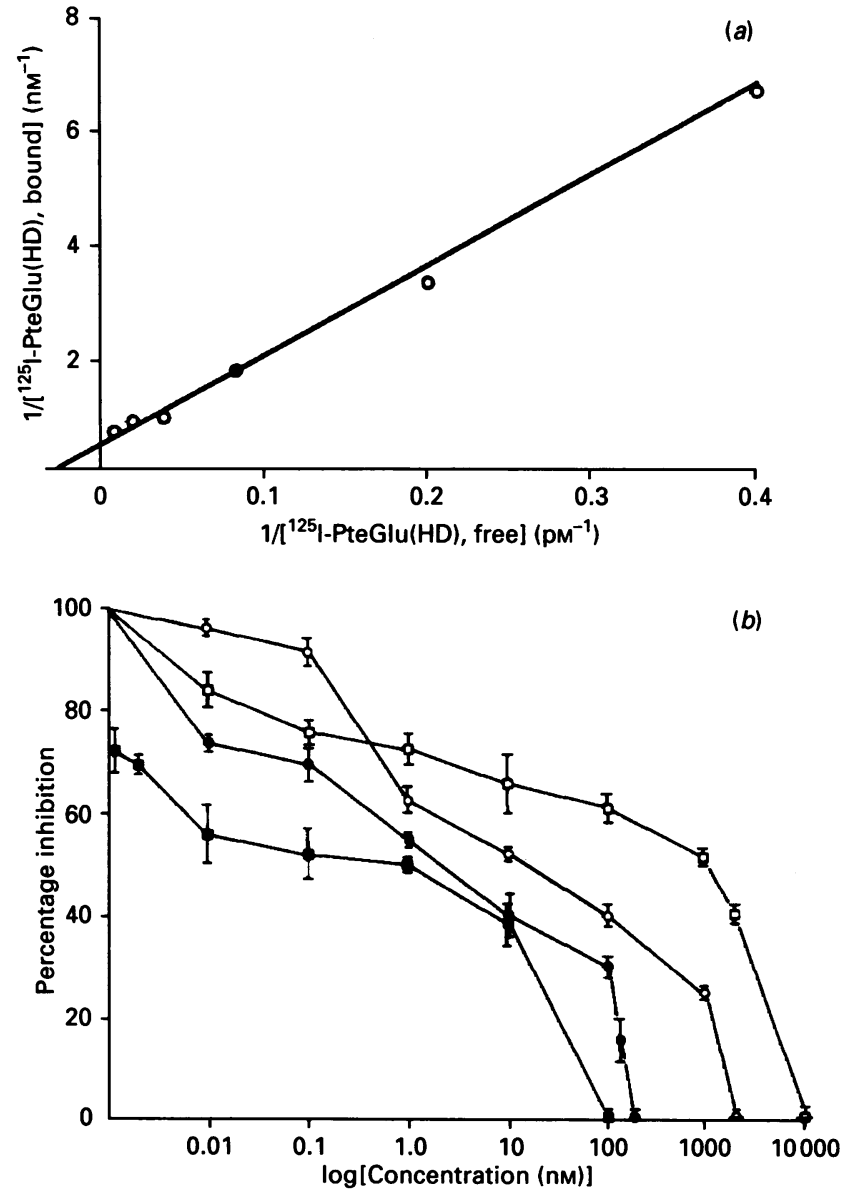

Fig. 6. Dissociation constant of ${ }^{125} \mathrm{I}-\mathrm{PteGlu}(\mathrm{HD})$ for purified f-FBPs (a) and competitive inhibition of $\left[{ }^{3} \mathbf{H}\right]$ PteGlu-binding of $\mathrm{f}-\mathrm{FBPs}$ by unlabelled folates $(b)$

Partially purified (CM eluate) f-FBPs were suspended with 3 pmol of $\left[{ }^{3} \mathrm{H}\right] \mathrm{PteGlu}$ in the absence (maximum bound) and presence of increasing concentrations of PteGlu $(\boldsymbol{\square})$, 5-methyltetrahydrofolate $(\square), 5$-formyltetrahydrofolate $(O)$ or methotrexate $(O)$ in a final volume of $250 \mu \mathrm{l}$ in PT. After incubation for $1 \mathrm{~h}$ at $37^{\circ} \mathrm{C}$, the samples were assayed for bound and free radioactivity. The value for $100 \%\left[{ }^{3} \mathrm{H}\right]$ PteGlu binding (no inhibition) was $0.3 \mathrm{pmol}$.

separate free $\mathrm{Na}^{125} \mathrm{I}$ ), this finding lent further support to their apparent homogeneity, since no other contaminating iodinated proteins were identified. Isoelectric focusing (not shown) revealed that with nf-FBPs, $66 \%$ of the total radioactivity was recovered

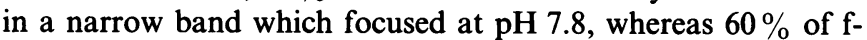
FBPs were recovered in a narrow band which focused at $\mathrm{pH} 8$ with a minor peak (less than $5 \%$ ) at $\mathrm{pH} 3.5$.

In the absence of Triton X-100, we were unable to detect ${ }^{125} \mathrm{I}$ PteGlu(HD) binding to f-FBPs even after removal of endogenous folate. With increasing concentrations of Triton X-100 there was a progressive increase in radioligand binding by f-FBPs (Table 6) for which there is no precedence among other human FBPs previously studied. nf-FBPs, on the other hand, failed to bind radiolabelled folate in the absence or presence of Triton X-100. Since other hydrophobic FBPs bind significant quantities of detergent which accounts for their aberrant elution on gel filtration in the presence of Triton $X-100[1,12,15,18]$, we investigated whether the Triton X-100-dependence of f-FBPs for optimal ligand binding was due to Triton X-100 micelle binding. Sucrose-density-gradient ultracentrifugation of both FBPs in water and ${ }^{2} \mathrm{H}_{2} \mathrm{O}$ above the critical micellar concentration of 
Table 6. Effect of Triton X-100 on the binding of ${ }^{125} \mathrm{I}-\mathrm{PteGlu}(\mathrm{HD})$ to f-FBPs

Crude processed human saliva $(250 \mu \mathrm{l})$ was incubated with ${ }^{125} \mathrm{I}$ PteGlu(HD) $(25 \mathrm{fmol})$, in a final volume of $1 \mathrm{ml}$ containing $10 \mathrm{~mm}$ $\mathrm{K}_{2} \mathrm{PO}_{4}, \mathrm{pH} 7.5$, and various concentrations of Triton X-100. After incubation for $30 \mathrm{~min}$ at $37^{\circ} \mathrm{C}$, the samples were cooled to $4{ }^{\circ} \mathrm{C}$ and successively analysed by h.p.l.c. gel filtration for radioligand binding. The maximal binding ( $100 \%$ ) was $10 \mathrm{fmol}$ of ${ }^{125} \mathrm{I}-\mathrm{PteGlu}(\mathrm{HD}) / \mathrm{ml}$ of crude saliva.

\begin{tabular}{cc}
\hline & $\begin{array}{c}\text { Percentage } \\
\text { Concentration of } \\
\text { Triton X-100 (\%) }\end{array}$ \\
$\begin{array}{c}\text { 125 I-PteGlu(HD) } \\
\text { binding }\end{array}$ \\
\hline 0 & 0 \\
0.25 & 18 \\
0.50 & 36 \\
0.75 & 80 \\
1.00 & 100 \\
1.50 & 100
\end{tabular}

Triton X-100 failed to reveal Triton X-100 micelle binding (not shown). This was manifested by no apparent differences in sedimentation profile in water compared with ${ }^{2} \mathrm{H}_{2} \mathrm{O}$, similar to hydrophilic PFR $[12,18]$, and both species co-sedimented with $40000-M_{\mathrm{r}}$ marker proteins, consistent with the data obtained from S-200 gel filtration in Triton X-100.

\section{DISCUSSION}

Several prerequisites were experimentally verified before we were confident about identification of two distinct immunoreactive FBPs in human placenta. These relate to $(a)$ the purity of the PFR used to raise antibodies, $(b)$ the specificity of the antiPFR antibodies, (c) validation of the radioimmunoassay for PFR, (d) inability to unmask additional putative cryptic folatebinding sites in saliva and $(e)$ experimental reassurance that saliva did not contain an inhibitor or factor that destroyed the ligand-binding site of purified PFR. The first three prerequisites have been met through extensive analysis reported in prior publications from our laboratory, and verification of the last two prerequisites have been satisfied experimentally by the results of the present study. Thus our failure to correlate the amount of folate bound with the theoretical ligand-binding capacity of the experimentally quantified CRM supported the conclusion that there existed two species of immunoreactive FBP-like species in normal saliva: one which bound folate (f-FBP) and another CRM to PFR (nf-FBP) which was presumably present in quantitatively greater amounts ( $>30$-fold).

Since hydrophobic FBPs and (native) PFR are linked to the membrane through GPI anchors [21,22], it could therefore be argued that nf-FBP was only related to f-FBP and PFR through the common epitope (the cross-reacting determinant) in GPIanchored proteins. Against this is the fact that the antigen used to generate anti-PFR serum [36] did not contain this moiety since (a) hydrophilic PFR (the antigen) was the product of endoproteolytic degradation of native hydrophobic PFR through the action of endogenous metalloproteinases $[16,18,19]$, and $(b)$ this hydrophilic fragment containing the ligand-binding site (hydrophilic PFR) was purified distinct from its hydrophobic GPI-anchored domain which would contain the cross-reacting determinant [22].

Another issue relates to the extremely poor quantitative data obtained by purified salivary FBPs when tested in the radioimmunoassay for PFR; this radioimmunoassay was based on anti-PFR serum recognition of purified PFR, which was also the tracer used. Under these conditions, proteins with shared anti- genic determinants to PFR would be specifically identified irrespective of whether the degree of epitope sharing was strong or weak. In the latter instance, the only distinguishing feature would be the greater quantity of protein required to overcome anti-PFR serum recognition of radioiodinated PFR tracer. Alternatively, this could be a function of a small amount of FBP in an unpurified protein preparation; however, the purified nfFBP and f-FBP did not contain contaminants. Thus we must conclude that the observed lack of correlation between the quantification of CRM with the quantification of protein was a function of weak sharing of antigenic determinants between PFR and $\mathrm{nf}-\mathrm{FBP}$ and f-FBP. We have previously shown the in vitro generation and acquisition of an iodinated species of PFR from a purified PFR preparation that did not react with anti-PFR serum as well as the native affinity-purified ${ }^{125}$ I-labelled PFR in immunoprecipitation and radioimmunoassay studies [34]. This precedent derived in vitro supports the concept that an antigenically identical FBP species could somehow be generated in saliva in vivo with profound alteration in folate-binding capacity and reaction with specific antiserum when compared with prototypical FBPs such as PFR. Thus the observed weak correlation between the amount of nf-FBP/F-FBP and the equivalence of CRM in the PFR radioimmunoassay predicted significant differences between the two salivary FBPs from other human FBPs. This evidence was obtained from $(a)$ the distinctly different order of specificity for various folate analogues (relative $\mathrm{IC}_{50}$ with $\mathrm{f}$ FBP compared with PFR), as well as the demonstrated necessity for Triton X-100 for optimal exhibition of ligand binding. Although this latter feature of f-FBP has no precedent among human FBPs, soluble FBP in cow's whey has been shown to exhibit virtually identical characteristics [38]. The fact that detergents help in the unfolding of polypeptides by interacting at hydrogen-binding sites, thus making the protein more linear [39], raises the possibility that analogous mechanisms may exist for $\mathrm{f}$ FBPs in vivo. Whereas surface-active substances (lipids or detergents) are required for the maximal activity of several membrane-derived proteins, we have no information as to whether $\mathrm{f}$ FBP is derived from membrane FBP. Nevertheless, although saliva is not known to contain detergent, it will be of interest to study the possible role of endogenous bile salts in modulating folate-binding capacity of f-FBPs in vivo; this may be of relevance at sites of folate absorption in the intestine.

Although the significance of nf-FBPs in saliva is not yet known, their presence there must eventually be considered within the context of folate and FBP metabolism $[1,2,40]$. Despite the identification of diverse proteins with very little or no similarity in their primary structure which interact with folates [40], the biochemistry of immunologically related proteins to high-affinity FBPs which do not bind folates has not been described. Whereas the existence of nf-FBP could be explained by numerous possibilities, our studies have eliminated those related to $(a)$ occupancy of the ligand-binding site by folate, $(b)$ the presence of an inhibitor of folate binding in saliva, $(c)$ destruction of the ligand-binding site of a FBP shortly after its synthesis by some moiety in saliva or $(d)$ limited proteolysis of the FBP by salivary proteinases. In addition, nf-FBP was $(e)$ not a CRM with a different preferred ligand from folates, and $(f)$ not an aglycosylated form of FBP which has not yet been post-translationally processed to acquire a functionally active ligand-binding site. However, we cannot rule out the possibility of nf-FBP being a regulated product in folate homoeostasis, since only normal (non-folate-deficient) subjects were donors of saliva. Also, the possibility that nf-FBP represents an unprocessed precursor in saliva which, through interaction with gastrointestinal secretions, acquires ligand-binding capacity, leading to a modulatory role in intestinal folate homoeostasis, remains to be tested. 
Although FBP cDNA clones coding for 262 amino acids (f-FBP) have not yet been reported, the heterogeneity among numerous FBP cDNA clones isolated thus far [23-27] strongly suggests that further analysis will reveal larger FBP cDNA clones. On the other hand, analysis of the cDNA for nf-FBP would be of some significance if the deduced amino acid sequence shared some, but not complete, identity with the known FBP cDNAs; such information could lead to clues regarding $(a)$ the ligand-binding domain of FBPs, $(b)$ related members of the folate receptor/FBP multi-gene family and $(c)$ additional genes which, together with FBP, may constitute a putative new superfamily of genes. Despite many similarities and differences between nf-FBP and f-FBP, none of our studies have ruled out the possibility that nf-FBP is not structurally related to f-FBP; since preliminary $N$-terminal analysis revealed no sequence information, analysis for internal amino-acid-sequence similarities will be necessary to investigate this possibility.

The functional role of soluble FBPs in human tissues is unknown. Although it has been suggested that milk FBPs may modulate folate absorption, the interrelationship between folate absorption involving PteGlu ${ }^{-} / \mathrm{OH}^{-}$co-transport and/or $\mathrm{PteGlu}^{-}-\mathrm{H}^{+}$exchange and extracellular (luminal) FBPs and enteric cell-membrane-associated FBPs in this process has not been completely elucidated [40]. It is important to point out that in none of these studies involving soluble FBP have actual gastrointestinal secretion-derived FBPs been used. The normal adult secretes approx. 1.5 litres of saliva daily. On the basis of a $29 \%$ recovery, we purified $0.71 \mathrm{mg}$ of nf-FBPs from $800 \mathrm{ml}$ of saliva; this translates to approx. $4.6 \mathrm{mg}$ of nf-FBPs secreted daily. If all of these nf-FBPs were converted into f-FBPs, this would translate to a total folate-binding capacity of 90$100 \mathrm{nmol} /$ day by 'activated' nf-FBPs. Coincidentally, the minimal daily requirement of folate in humans is $50 \mu \mathrm{g} /$ day [40]; the net amount of pteroylglutamates in the intestinal lumen (from food folates) would therefore be approx. $100 \mathrm{nmol}$ of folate, a level that would completely saturate the functionally 'activated' nf-FBPs. On the basis of these theoretical values, we suggest that it is possible that post-translational or post-secretory modifications of nf-FBPs within the intestinal lumen may result in their conversion into f-FBPs, which would then probably modulate folate absorption.

We thank Stephanie McGillem for expert secretarial assistance, Steve $R$. Kincade for technical assistance in the early phases of this study, and Dr. S. Schenker, Dr. G. I. Henderson and Dr. A. J. Zubrowka for helpful discussions. We are indebted to Dr. J. Fred Kolhouse, University of Colorado Health Sciences Center, Denver, CO, U.S.A., for assistance with amino acid and carbohydrate analysis. This work was supported by grants from the National Institute of Child Health and Human Development (no. HD 20889) and the Alcohol, Drug Abuse and Mental Health Administration (no. AA 08307) awarded to A.C.A.

\section{REFERENCES}

1. Antony, A. C. (1992) Blood 79, 2807-2820

2. Henderson, G. B. (1990) Annu. Rev. Nutr. 10, 319-335

3. Antony, A. C., Kane, M. A., Portillo, R. M., Elwood, P. C. \& Kolhouse, J. F. (1985) J. Biol. Chem. 260, 14911-14917

4. Kane, M. A., Portillo, R. M., Elwood, P. C., Antony, A. C. \& Kolhouse, J. F. (1986) J. Biol. Chem. 261, $44-49$
5. Deutsch, J. C., Elwood, P. C., Portillo, R. M., Macey, M. G. \& Kolhouse, J. F. (1989) Arch. Biochem. Biophys. 274, 327-337

6. Jansen, G., Westerhof, G. R., Kathmann, I., Rademaker, B. C., Rijksen, G. \& Schornagel, J. H. (1989) Cancer Res. 49, 2455-2459

7. Jansen, G., Westerhof, G. R., Jarmuszewski, J. A., Kathmann, I., Rijksen, G. \& Schornagel, J. H. (1990) J. Biol. Chem. 265, 18272-18277

8. Sadasivan, E., Rothenberg, S. P., daCosta, M. \& Brink, L. (1986) Biochim. Biophys. Acta 882, 311-321

9. Anthony, A. C., Kincade, R. S., Verma, R. S. \& Krishnan, R. S. (1987) J. Clin. Invest. 80, 711-723

10. Antony, A. C., Bruno, E., Briddell, R., Brandt, J. E., Verma, R. S. \& Hoffman, R. (1987) J. Clin. Invest. 80, 1618-1623

11. Antony, A. C., Briddell, R. A., Brandt, J. E., Straneva, J. E., Verma, R. S., Miller, M. E., Kalasinski, L. A. \& Hoffman, R. (1991) J. Clin. Invest. 87, 313-325

12. Antony, A. C., Ultey, C. S., Marcell, P. D. \& Kolhouse, J. F. (1982) J. Biol. Chem. 257, 10081-10089

13. Elwood, P. C., Kane, M. A., Portillo, R. M. \& Kolhouse, J. F. (1986) J. Biol. Chem. 261, 15416-15423

14. Luhrs, C. A., Sadasivan, E., daCosta, M. \& Rothenberg, S. P. (1986) Arch. Biochem. Biophys. 250, 94-105

15. Kane, M. A., Elwood, P. C., Portillo, R. M., Antony, A. C. \& Kolhouse, J. F. (1986) J. Biol. Chem. 261, 15625-15631

16. Verma, R. S. \& Antony, A. C. (1991) J. Biol. Chem. 266, 12522-12535

17. Antony, A. C. \& Verma, R. S. (1989) Biochim. Biophys. Acta 979, $62-68$

18. Antony, A. C., Verma, R. S., Unune, A. R. \& LaRosa, J. A. (1989) J. Biol. Chem. 264, 1911-1914

19. Elwood, P. C., Deutsch, J. C. \& Kolhouse, J. F. (1991) J. Biol. Chem. 266, 2346-2353

20. Luhrs, C. A., Pitiranggon, P., daCosta, M., Rothenberg, S. P., Slomiany, B. L., Brink, L., Tous, G. I. \& Stein, S. (1987) Proc. Natl. Acad. Sci. U.S.A. 84, 6546-6549

21. Luhrs, C. A. \& Slomiany, B. L. (1989) J. Biol. Chem. 264, 21446-21449

22. Verma, R. S., Gullapalli, S. \& Antony, A. C. (1992) J. Biol. Chem. 267, 4119-4127

23. Sadasivan, E. \& Rothenberg, S. P. (1989) J. Biol. Chem. 264, 5806-5811

24. Elwood, P. C. (1989) J. Biol. Chem. 264, 14893-14901

25. Lacey, S. W., Sanders, J. M., Rothberg, K. G., Anderson, R. G. W. \& Kamen, B. A. (1989) J. Clin. Invest. 84, 715-720

26. Ratnam, M., Marquardt, H., Duhring, J. L. \& Freisheim, J. H. (1989) Biochemistry 28, 8249-8254

27. Campbell, I. G., Jones, T. A., Foulkes, W. D. \& Trowsdale, J. (1991) Cancer Res. 51, 5329-5338

28. Zheng, D. B., Lim, H. M., Pene, J. J. \& White, H. B. (1988) J. Biol. Chem. 263, 11126-11129

29. Ford, J. E. (1974) Br. J. Nutr. 31, 243-257

30. Colman, N., Hettiarachchy, N. \& Herbert, V. (1981) Science 211, $1427-1428$

31. Tani, M. \& Iwai, K. (1984) J. Nutr. 114, 778-785

32. Said, H. M., Horne, D. W. \& Wagner, C. (1986) Arch. Biochem. Biophys. 251, 114-120

33. Pristoupilová, K. \& Slavíková, V. (1980) Cas. Lék. Cesk. 119, 40-41

34. Antony, A. C., Verma, R. S. \& Kincade, R. S. (1987) Anal. Biochem. 166, 224-235

35. Kane, M. A., Elwood, P. C., Portillo, R. M., Antony, A. C., Najfeld, V., Finley, A., Waxman, S. \& Kolhouse, J. F. (1988) J. Clin. Invest. 81, 1398-1406

36. Antony, A. C., Utley, C., Van Horne, K. C. \& Kolhouse, J. F. (1981). J. Biol. Chem. 256, 9684-9692

37. Reissnauer, A. M. (1990) Biochem. J. 267, 249-252

38. Hansen, S. I., Holm, J. \& Lyngbye, J. (1982) Clin. Chem. 28, $117-118$

39. Andrews, P. (1965) Biochem. J. 96, 595-606

40. Antony, A. C. (1991) in Hematology: Basic Principles and Practice (Hoffman, R., Benz, E. J., Shattil, S. J., Furie, B. \& Cohen, H. J., eds.), pp. 392-422, Churchill-Livingstone, New York 